\title{
Analysis of Bacteriolytic Activity Patterns, a Novel Approach to the Taxonomy of Enterococci
}

\author{
RAFFAELLO POMPEI, ${ }^{1 *}$ MARIA C. THALLER,${ }^{2}$ FABRIZIA PITTALUGA,${ }^{3}$ ORNELLA FLORE, ${ }^{1}$ \\ AND GIUSEPPE SATTA ${ }^{4}$ \\ Istituto di Microbiologia, Università di Cagliari; via Porcell 4, 09100 Cagliari, ${ }^{1}$ Istituto di Microbiologia, Università \\ di Roma La Sapienza, 00184 Rome, ${ }^{2}$ Istituto di Microbiologia, Università di Verona, 37134 Verona, ${ }^{3}$ \\ and Istituto di Microbiologia, Università Cattolica del Sacro Cuore, 00167 Rome,${ }^{4}$ Italy
}

\begin{abstract}
The bacteriolytic activities of different group D streptococcal species on various media and substrates were studied. Our results showed that all of the enterococcal species which we tested had bacteriolytic activity on at least one of the media used, while the group D nonenterococcal species had no such activity. In addition, using culture media containing different additives and different $\mathrm{pH}$ values, we defined seven major groups of bacteriolytic activity (lyogroups), each of which overlapped with one species (four lyogroups), two species (two lyogroups), or four species (one lyogroup). The detection of enterococcal lyogroups proved to be as reliable for species identification as the conventional methods presently in use.
\end{abstract}

The genus Enterococcus was proposed for the species Enterococcus faecalis and Enterococcus faecium (34), and subsequently Enterococcus avium, Enterococcus gallinarum, Enterococcus durans, Enterococcus casseliflavus, and Enterococcus malodoratus were described (7). More recently, Enterococcus mundtii, Enterococcus hirae $(5,15)$, Enterococcus solitarius, Enterococcus raffinosus, and Enterococcus pseudoavium have been recognized (4).

Although in general new taxonomic proposals for members of this genus have been based on the results of highly reliable procedures, such as DNA hybridization (20), determination of ubiquinone contents of cell membranes (6), and the use of penicillin-binding proteins (43), the taxonomy of the enterococci has not been completely defined yet, and confirmation on the basis of completely different, independent properties would be a great help in achieving more rapid and wider acceptance of these taxa $(3,8-10,13,14,17,18$, 27). In addition, recognition of new species proposed on the basis of the results of conventional methods involves testing many different characteristics, which makes identification rather complex and expensive, particularly in routine clinical microbiology laboratories. Therefore, alternative methods for routine identification of enterococci at the species level would be highly desirable $(10,29,43)$. Reliable species definition among the group D streptococci is important for medicine, since the roles played in human pathology by the different species in the group may be quite different $(1,2,19$, $21,22-25,35$ ).

It has been shown previously that all isolates of the genus Staphylococcus secrete bacteriolytic enzymes $(32,33)$ and that the lytic activity patterns of the strains of the various species are different $(37,41,42)$.

Similarly, in this work we analyzed the production and properties of bacteriolytic activity in enterococci and some other group D streptococci. We found that this activity is present in all strains of the genus Enterococcus and in none of the other group D streptococci which we tested.

In addition, the strains of the different enterococcal species produced bacteriolytic enzymes with different properties, enabling us to set up a novel scheme for enterococcal identification, which is as reliable as conventional schemes.

\footnotetext{
* Corresponding author
}

\section{MATERIALS AND METHODS}

Bacterial strains. Human strains of group D streptococci were isolated from clinical specimens in the Clinical Microbiology Laboratory of the Institute of Microbiology of the University of Cagliari from 1983 to 1986 . Reference human streptococci and some nonhuman reference strains were obtained from the Czechoslovak Culture Collection (CCM) and from the American Type Culture Collection (ATCC), Rockville, Md. (see Table 4). A number of strains of $E$. hirae and $E$. durans were kindly provided by J. Coyette (Universitè de Lièges).

Biochemical and enzymatic tests. Streptococci were identified by using the criteria proposed by Facklam (11) and Facklam and Carey (12); we performed additional tests as described by Collins et al. (7), Farrow et al. (16), and Schleifer and Kilpper-Bälz (34). A commercial API 20 Strep system (Ayerst Italiana) was also used.

Detection of bacteriolytic activity. To detect bacteriolytic activity, double-layer agar plates containing various media were used, as previously described $(26,32)$. Lytic activity was always recorded after $48 \mathrm{~h}$ of incubation at $37^{\circ} \mathrm{C}$ (unless otherwise indicated). The halos of lytic activity were scored as follows: $1+$ (less than $1 \mathrm{~mm}$ of lysis from the edge of the colony), $2+$ (from 1 to $2 \mathrm{~mm}$ of lysis), $3+$ (from 2 to $3 \mathrm{~mm}$ of lysis), $4+$ (more than $3 \mathrm{~mm}$ of lysis), or - (no lysis). The plates were read at least three times by different observers before a score for bacteriolytic activity was recorded.

Bacteriolytic activity was analyzed on several different media; a total of 27 different combinations were used (Table 1). Brain heart infusion agar, Mueller-Hinton agar, Columbia blood agar base, and tryptose agar (TA) were obtained all from Difco; Todd-Hewitt medium was obtained from both Difco (THD) and Oxoid (THO). Streptococcus selective agar (SSA) was purchased from Biolife, Milan, Italy. Bile salts (Difco) were added to TA before sterilization at a concentration of either 0.01 or $0.04 \%$; sodium azide was added to THO at a concentration of $0.02 \%$. Suramin (Germanine; Bayer) and potassium tellurite (Sigma) were prepared as $100 \times$ solutions, presterilized by filtration, and added to autoclaved media (kept at $45^{\circ} \mathrm{C}$ ) to the final desired concentrations; suramin was used at concentrations of 300,500 , and $1,000 \mu \mathrm{g} / \mathrm{ml}$ in both TA and SSA, and potassium tellurite was used at a concentration of $100 \mu \mathrm{g} / \mathrm{ml}$ only in TA. TA without 
TABLE 1. Bacteriolytic activities of group D streptococci on different media containing heat-killed cells of $M$. lysodeikticus or M. luteus

\begin{tabular}{|c|c|c|c|c|c|c|c|c|c|c|c|c|}
\hline \multirow[b]{2}{*}{$\begin{array}{l}\text { No. of } \\
\text { strains }\end{array}$} & \multicolumn{12}{|c|}{ Formation of zones of transparency around bacterial growth on the following medium ${ }^{a}$ : } \\
\hline & THD & $\begin{array}{l}\text { THO }+0.02 \% \\
\text { sodium azide }\end{array}$ & $\begin{array}{c}\text { Brain heart } \\
\text { infusion } \\
\text { agar }\end{array}$ & $\begin{array}{l}\text { Mueller- } \\
\text { Hinton } \\
\text { agar }\end{array}$ & $\begin{array}{c}\text { Columbia } \\
\text { blood } \\
\text { agar }\end{array}$ & TA & $\begin{array}{c}\mathrm{TA}+0.01 \% \\
\text { bile salts }\end{array}$ & $\begin{array}{c}\mathrm{TA}+0.04 \% \\
\text { bile salts }\end{array}$ & $\begin{array}{c}\mathrm{TA}+0.03 \% \\
\text { suramin }\end{array}$ & $\begin{array}{c}\mathrm{TA}+0.05 \% \\
\text { suramin }\end{array}$ & $\begin{array}{c}\mathrm{TA}+0.1 \% \\
\text { suramin }\end{array}$ & $\begin{array}{c}\text { TA } \\
\text { without } \\
\text { salt }\end{array}$ \\
\hline 98 & $3+$ & $3+$ & $3+$ & $2+$ & $3+$ & $3+$ & $3+$ & $2+$ & $1+$ & - & - & $3+$ \\
\hline 43 & $3+$ & $1+$ & $2+$ & $2+$ & $2+$ & $3+$ & $2+$ & $2+$ & $2+$ & $2+$ & $2+$ & $2+$ \\
\hline 3 & $3+$ & - & $2+$ & - & $1+$ & $3+$ & $2+$ & $1+$ & $2+$ & $2+$ & $2+$ & $2+$ \\
\hline 6 & $1+$ & - & - & - & - & - & - & - & - & - & - & - \\
\hline 2 & - & $\mathrm{NG}^{\mathrm{c}}$ & - & - & - & - & - & - & - & $\mathrm{NG}$ & $\mathrm{NG}$ & - \\
\hline
\end{tabular}

a $1+, 2+, 3+$, and $4+$ indicate increasing halos of bacteriolytic activity around streptococcal colonies; a minus sign indicates no lysis. Unless indicated otherwise the preparations contained the strain of $M$. lysodeikticus obtained from Sigma as the substrate for lysis.

${ }^{b}$ These preparations contained lysis-hypersensitive strain ML-Ca as the substrate for lysis.

c NG, no growth occurred on these media.

salt was prepared by mixing the compounds as indicated by the manufacturer for the commercial medium but not adding $\mathrm{NaCl}$; TA and SSA supplemented with 2, 4, and $6 \%$ (final concentrations) $\mathrm{NaCl}$ were made by adding enough $\mathrm{NaCl}$ to the commercial TA and SSA preparations to give these concentrations. TA at $\mathrm{pH} 9.6$ was made by adding $1 \mathrm{~N}$ $\mathrm{NaOH}$ to the commercial medium. Finally, the bacteriolytic activity of streptococci was also studied in TA that was incubated for $48 \mathrm{~h}$ in an incubator at $42^{\circ} \mathrm{C}$.

As the substrates for lysis, we used either a commercial lyophilized preparation of Micrococcus lysodeikticus obtained from Sigma or Micrococcus luteus ML-Ca; the latter is a mutant of strain $\mathrm{AH}-47$, which has been described elsewhere (40), and was selected because it is hypersensitive to bacteriolytic activity.

Preparation of $\boldsymbol{M}$. luteus suspensions. $M$. luteus ML-Ca was grown on brain heart infusion agar plates containing 0.03 $\mathrm{M} \mathrm{MgCl}$ for 3 to 5 days at $30^{\circ} \mathrm{C}$. The cells were then collected, washed twice with saline, and packed by centrifugation. They were suspended again in saline and sterilized by autoclaving at $121^{\circ} \mathrm{C}$ for $15 \mathrm{~min}$. Washing, centrifugation, and autoclaving were repeated once more. Then the cells were suspended in sterile saline to an optical density at 640 of 200 and kept in a refrigerator ready to be added to melted agar media to reach a final optical density of 4 . A suspension of $M$. lysodeikticus was prepared from commercial lyophilized powder (Sigma) by using the same procedure.

\section{RESULTS}

Patterns of bacteriolytic activity demonstrated by 152 group D streptococci, evaluated by using a large number of assay media. In order to evaluate the frequency of bacteriolytic activity by group D streptococci, a total of 152 strains, including fresh isolates (the majority of the strains) and strains taken at random from the collection of the Institute of Microbiology, University of Cagliari (including strains of both human origin and nonhuman origin), were inoculated into 27 different media containing two substrates. Table 1 shows that of the 152 strains tested, 150 demonstrated lytic activity on at least one of the media, while only 2 lacked such activity. In addition, the bacteriolytic activities of the various strains were not homogeneous on the different assay media, thus allowing us to subdivide all of the lytic strains into four main groups (lyogroups), each of which differed from the others in bacteriolytic activity pattern.

Subdivision of $\mathbf{5 7 2}$ group D streptococcal strains into lyogroups. Since the preliminary evaluation described above indicated that there was a good chance that the group D streptococci could be subdivided into lyogroups, we selected the 11 most indicative assay media and used them to analyze the bacteriolytic activities of 572 group D streptococci. Table 2 shows the various bacteriolytic activity patterns. Only four strains failed to exhibit lytic activity on any of the media, while all of the other strains were active under one or more conditions. These strains were divided into seven lyogroups. Lyogroup E-I was characterized by strong bacteriolytic activity on most of the media used; its activity was markedly inhibited in the media containing suramin. Lyogroup E-II had a reduced lytic activity pattern compared with lyogroup E-I; it was inhibited by sodium azide in THO, by $6 \% \mathrm{NaCl}$, and by $\mathrm{pH} 9.6$ and had the peculiar characteristic of strong activity on SSA. Lyogroup E-III contained

TABLE 2. Division of 572 strains of group D streptococci into lyogroups by using 11 selected test media

\begin{tabular}{|c|c|c|c|c|c|c|c|c|c|c|c|c|}
\hline \multirow[b]{2}{*}{$\begin{array}{l}\text { No. of } \\
\text { strains }\end{array}$} & \multicolumn{11}{|c|}{ Bacteriolytic activity on the following medium: } & \multirow[b]{2}{*}{ Lyogroup } \\
\hline & THD & $\begin{array}{c}\text { THO + } \\
0.02 \% \\
\text { sodium } \\
\text { azide }\end{array}$ & TA & $\begin{array}{c}\mathrm{TA}+ \\
0.04 \% \\
\text { bile } \\
\text { salts }\end{array}$ & $\begin{array}{c}\mathrm{TA}+ \\
0.05 \% \\
\text { suramin }\end{array}$ & $\begin{array}{c}\mathrm{TA}+ \\
4 \% \\
\mathrm{NaCl}\end{array}$ & $\begin{array}{c}\mathrm{TA}+ \\
6 \% \\
\mathrm{NaCl}\end{array}$ & $\begin{array}{c}\mathrm{TA} \text { at } \\
\mathrm{pH} \\
9.6\end{array}$ & SSA & $\begin{array}{c}\text { SSA + } \\
0.05 \% \\
\text { suramin }\end{array}$ & $\begin{array}{l}\text { SSA + } \\
\text { ML-Ca }\end{array}$ & \\
\hline 483 & $3+$ & $\overline{3+}$ & $3+$ & $2+$ & $-b$ & $3+$ & $2+$ & $4+$ & $2+$ & - & $2+$ & E-I \\
\hline 46 & $3+$ & $1+$ & $3+$ & $2+$ & $2+$ & $2+$ & $1+$ & - & $3+$ & $2+$ & $3+$ & E-II \\
\hline 8 & $3+$ & - & $3+$ & $1+$ & $2+$ & - & - & - & $1+$ & $1+$ & $2+$ & E-III \\
\hline 13 & $1+$ & _- & 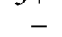 & - & - & - & - & - & - & - & $1+$ & E-IV \\
\hline 9 & $4+$ & $3+$ & $3+$ & $3+$ & $3+$ & $2+$ & $2+$ & $2+$ & $2+$ & $1+$ & $4+$ & E-V \\
\hline 4 & $2+$ & $2+$ & $2+$ & - & $1+$ & $1+$ & - & $1+$ & - & - & $2+$ & E-VI \\
\hline 5 & $2+$ & $1+$ & $2+$ & $1+$ & - & $1+$ & - & $2+$ & - & - & - & E-VII \\
\hline 4 & - & $\mathbf{N G}^{c}$ & 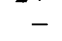 & - & NG & NG & NG & - & NG & NG & NG & 0 \\
\hline
\end{tabular}

${ }^{a}$ On this medium the substrate for lysis was $M$. luteus ML-Ca. On all of the other media the substrate for lysis was $M$. lysodeikticus obtained from Sigma.

$b-$, no lysis.

${ }^{c}$ NG, no growth. 
TABLE 1-Continued

\begin{tabular}{|c|c|c|c|c|c|c|c|c|c|c|c|c|c|c|c|}
\hline $\begin{array}{c}\mathrm{TA}^{+} \\
2 \% \\
\mathrm{NaCl}\end{array}$ & $\begin{array}{c}\mathrm{TA}+ \\
4 \% \\
\mathrm{NaCl}\end{array}$ & $\begin{array}{c}\mathrm{TA}+ \\
6 \% \\
\mathrm{NaCl}\end{array}$ & $\begin{array}{l}\text { TA } \\
\text { at } \\
42^{\circ} \mathrm{C}\end{array}$ & $\begin{array}{l}\text { TA at } \\
\mathrm{pH} 9.6\end{array}$ & $\begin{array}{c}\mathrm{TA}+0.01 \% \\
\text { potassium } \\
\text { tellurite }\end{array}$ & SSA & $\begin{array}{c}\mathrm{SSA}+ \\
0.03 \% \\
\text { suramin }\end{array}$ & $\begin{array}{c}\mathrm{SSA}+ \\
0.05 \% \\
\text { suramin }\end{array}$ & $\begin{array}{c}\mathrm{SSA}+ \\
0.1 \% \\
\text { suramin }\end{array}$ & $\begin{array}{c}\mathrm{SSA}+ \\
2 \% \\
\mathrm{NaCl}\end{array}$ & $\begin{array}{c}\mathrm{SSA}+ \\
4 \% \\
\mathrm{NaCl}\end{array}$ & $\begin{array}{c}\mathrm{SSA}+ \\
6 \% \\
\mathrm{NaCl}\end{array}$ & $\begin{array}{c}\mathrm{TA}+ \\
\mathrm{ML}^{+} \mathrm{Ca}^{b}\end{array}$ & $\begin{array}{c}\mathrm{SSA}+ \\
\mathrm{ML}^{+} \mathrm{Ca}^{b}\end{array}$ & $\begin{array}{l}\text { Lyo- } \\
\text { group }\end{array}$ \\
\hline $3+$ & $3+$ & $2+$ & $3+$ & $4+$ & $3+$ & $2+$ & $1+$ & - & - & $2+$ & $2+$ & $2+$ & $4+$ & $2+$ & E-I \\
\hline $2+$ & $1+$ & $1+$ & $1+$ & - & $1+$ & $3+$ & $3+$ & $2+$ & $2+$ & $2+$ & $1+$ & - & $3+$ & $3+$ & E-II \\
\hline $1+$ & - & - & $2+$ & - & $1+$ & $1+$ & $1+$ & $1+$ & $1+$ & - & - & - & $3+$ & $2+$ & E-III \\
\hline- & - & - & - & - & - & - & - & - & - & - & - & - & $1+$ & $1+$ & E-IV \\
\hline- & NG & NG & - & - & NG & NG & NG & $\mathrm{NG}$ & NG & NG & NG & $\mathrm{NG}$ & - & NG & 0 \\
\hline
\end{tabular}

strains that exhibited reduced lytic activity on all of the media except THD and TA; the bacteriolytic activity of these strains was only slightly affected by the addition of suramin to the media. The strains in lyogroup E-IV exhibited poor bacteriolytic activity on all of the media except THD and SSA containing strain ML-Ca as the substrate for lysis. A number of strains of nonhuman origin fell into lyogroup $\mathrm{E}-\mathrm{V}$, which was characterized generally by strong bacteriolytic activity except when the organisms were incubated in SSA to which suramin had been added. Lyogroup E-VI included four strains that were nonlytic in the presence of bile salts or $6 \% \mathrm{NaCl}$, in SSA, and in SSA containing suramin and weakly active in the presence of suramin. Lyogroup E-VII contained five strains which exhibited clear bacteriolytic activity only on THD, TA, and TA at pH 9.6 and a weak activity on THO containing sodium azide and TA containing bile salts. The four strains of group D streptococci that lacked any bacteriolytic activity were placed in group $\mathrm{O}$.

Identification of the 572 group D strains of streptococci subdivided into lyogroups and lyogroup identification of reference strains belonging to the major streptococcal group D species. All of the species were identified by analyzing as many as 22 different characteristics chosen from among those most often used for reliable species identification of group D streptococci. Table 3 shows the characteristics of the strains and their identities together with their previously defined lyogroups. It is evident that each of the seven lyogroups completely overlapped with one or more of the major species (one lyogroup overlapped with two species, and one lyogroup overlapped with three species). Lyogroup E-I contained only strains of $E$. faecalis (all of the $E$. faecalis strains were members of this lyogroup), while lyogroup E-II completely overlapped with $E$. faecium and $E$. durans. Lyogroups E-III, E-V, E-VI, and E-VII completely overlapped with $E$. casseliflavus, E. hirae, E. gallinarum, and $E$. mundtii, respectively. Lyogroup E-IV contained members of $E$. avium, E. pseudoavium, and $E$. raffinosus. No strains belonging to $E$. solitarius and $E$. malodoratus were found in our study. All of the strains that lacked bacteriolytic activity were identified as Streptococcus bovis, while none of the lytic strains was identified as a member of this species.

A number of the reference strains obtained from the ATCC and CCM were analyzed for bacteriolytic activity on the 11 media described above. Table 4 shows that the bacteriolytic activity patterns of the reference strains overlapped completely with the patterns of the strains which we identified members of the corresponding species. In addition, the reference $E$. malodoratus strains were found to fall into lyogroup E-I, and a strain of $E$. solitarius fell into lyogroup E-IV.

Simplified scheme for group D streptococcal species identi- fication. Table 1 clearly shows that the strains of most species can be identified simply on the basis of their lytic activities on six media (namely, THD, THO containing $0.02 \%$ sodium azide, TA containing $0.05 \%$ suramin, TA at pH 9.6, TA containing $0.04 \%$ bile salts, and SSA when the substrate is ML-Ca); in these media only $S$. bovis always lacked bacteriolytic activity. E. faecalis and E. malodoratus were included in lyogroup E-I, and $E$. durans fell into lyogroup E-II, as did E. faecium. E. solitarius, E. raffinosus, and $E$. pseudoavium fell into lyogroup E-IV, as did $E$.

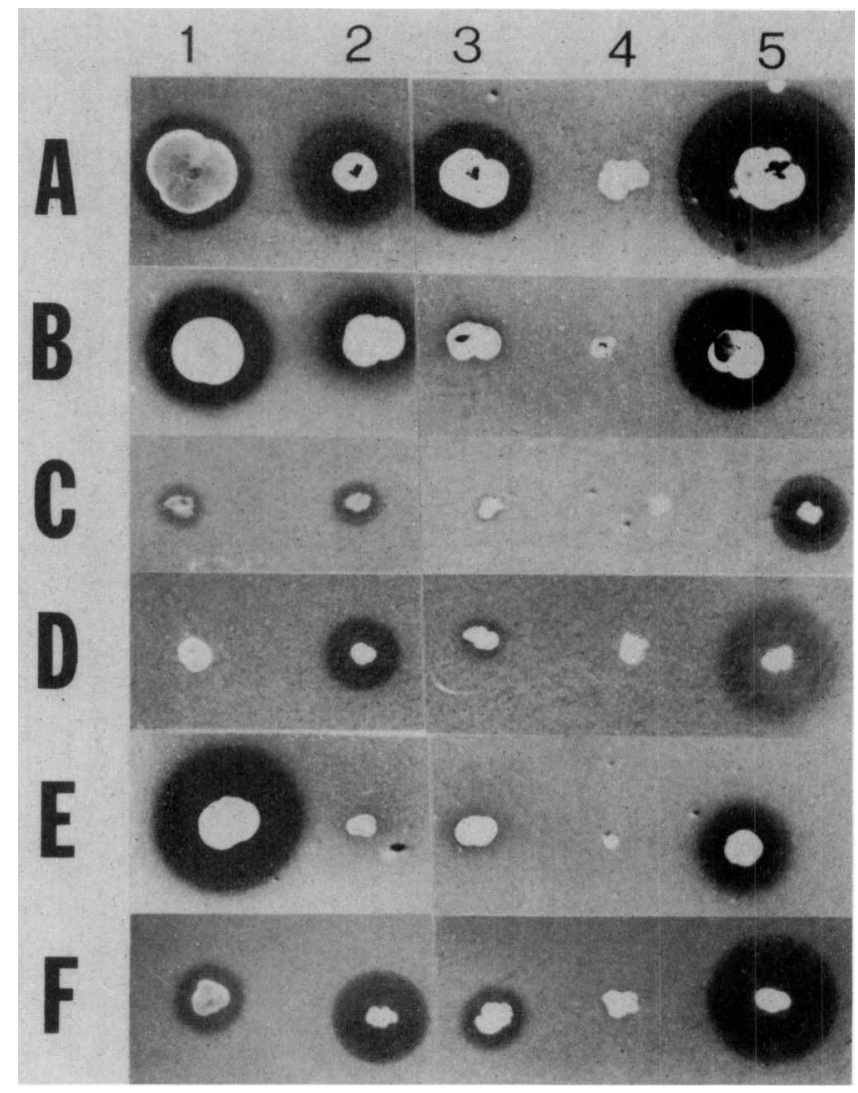

FIG. 1. Bacteriolytic activities of five species of enterococci on six media containing heat-killed cells of $M$. luteus. Species $1, E$. faecalis; species 2, E. faecium; species $3, E$. casseliflavus; species 4 E. avium; species 5, E. hirae. Medium A, THD; medium B, THO containing $0.02 \%$ sodium azide; medium C, TA containing $0.04 \%$ bile salts; medium D, TA containing $0.05 \%$ suramin; medium E, TA at $\mathrm{pH}$ 9.6; medium $\mathrm{F}$, SSA containing strain ML-CA as the substrate for lysis. The zones of lysis appear as dark halos around the colonies. 
TABLE 3. Identification of 572 group D streptococcal strains subdivided into lyogroups by biochemical and physiological tests

\begin{tabular}{|c|c|c|c|c|c|c|c|c|c|c|c|c|c|}
\hline \multirow{3}{*}{$\begin{array}{l}\text { No. of } \\
\text { strains }\end{array}$} & \multicolumn{13}{|c|}{ Reaction } \\
\hline & \multirow{2}{*}{$\begin{array}{c}\text { Bile } \\
\text { esculin }\end{array}$} & \multirow{2}{*}{$\begin{array}{c}\text { Group } \\
D \\
\text { antigen }\end{array}$} & \multirow{2}{*}{$\begin{array}{c}\text { Growth } \\
\text { in } 6.5 \% \\
\mathrm{NaCl}\end{array}$} & \multirow{2}{*}{$\begin{array}{l}\text { Tellu- } \\
\text { rite } \\
\text { reduc- } \\
\text { tion }\end{array}$} & \multirow{2}{*}{$\begin{array}{l}\text { Tetra- } \\
\text { zolium } \\
\text { reduc- } \\
\text { tion }\end{array}$} & \multicolumn{7}{|c|}{ Acid produced from: } & \multirow{2}{*}{$\begin{array}{l}\beta \text {-Galacto- } \\
\text { sidase }\end{array}$} \\
\hline & & & & & & Arabinose & Sorbitol & Mannitol & Glycerol & Raffinose & Sucrose & Pyruvate & \\
\hline 397 & + & + & + & + & + & - & + & + & + & - & + & + & - \\
\hline 35 & + & + & + & + & + & - & + & + & + & - & + & + & - \\
\hline 28 & + & + & + & - & + & - & + & + & + & - & + & + & - \\
\hline 23 & + & + & + & + & + & - & + & + & + & - & + & - & - \\
\hline 30 & + & + & + & - & - & + & - & + & - & - & + & - & + \\
\hline 6 & + & + & + & - & - & + & - & + & - & - & + & + & + \\
\hline 7 & + & + & + & - & + & + & - & + & - & - & + & - & + \\
\hline 3 & + & + & + & - & - & - & - & - & - & - & + & - & + \\
\hline 8 & + & + & + & - & $\mathrm{v}$ & + & $v$ & + & $\mathrm{v}$ & + & + & + & + \\
\hline 8 & + & $\mathbf{v}$ & + & - & + & + & + & + & $\mathrm{v}$ & - & + & - & - \\
\hline 2 & + & - & + & - & - & - & + & + & - & - & + & - & - \\
\hline 3 & + & $\mathbf{v}$ & + & - & - & + & + & + & + & + & + & - & - \\
\hline 9 & + & + & + & - & $v$ & - & - & - & - & + & + & - & + \\
\hline 4 & + & + & + & - & - & + & - & + & - & + & + & + & + \\
\hline 5 & + & + & + & - & + & + & $\mathrm{v}$ & + & - & + & + & + & + \\
\hline 4 & + & + & - & - & - & - & - & $\mathrm{v}$ & - & + & + & - & - \\
\hline
\end{tabular}

avium. On the basis of our findings, we set up a novel scheme for enterococcal species identification, which included the tests mentioned above and, in addition, arabinose and raffinose fermentation and the arginine dehydrolase test, to differentiate $E$. faecalis from $E$. malodoratus, $E$. durans from $E$. faecium, and $E$. raffinosus, $E$. solitarius, and $E$. pseudoavium from $E$. avium. Table 5 shows that when this scheme was used, a total of 285 strains, including all of the nonlytic organisms, could be accurately identified.

The bacteriolytic activity patterns of the five main enterococcal species which we tested in six different media are shown in Fig. 1.

Bacteriolytic activity of streptococcal strains belonging to antigenic groups other than group $D$. Table 6 shows the

TABLE 4. Bacteriolytic activities of reference group D streptococcal species on different media

\begin{tabular}{|c|c|c|c|c|c|c|c|c|c|c|c|c|c|}
\hline \multirow[b]{2}{*}{ Species } & \multirow[b]{2}{*}{ Strain } & \multicolumn{11}{|c|}{ Bacteriolytic activity on the following medium ${ }^{a}$ : } & \multirow[b]{2}{*}{$\begin{array}{l}\text { Lyo- } \\
\text { group }\end{array}$} \\
\hline & & THD & $\begin{array}{c}\text { THO + } \\
0.02 \% \\
\text { sodium } \\
\text { azide }\end{array}$ & TA & $\begin{array}{c}\text { TA + } \\
0.04 \% \\
\text { bile } \\
\text { salts }\end{array}$ & $\begin{array}{c}\mathrm{TA}+ \\
0.05 \% \\
\text { suramin }\end{array}$ & $\begin{array}{c}\mathrm{TA}+ \\
4 \% \\
\mathrm{NaCl}\end{array}$ & $\begin{array}{c}\mathrm{TA}+ \\
6 \% \\
\mathrm{NaCl}\end{array}$ & $\begin{array}{c}\mathrm{TA} \text { at } \\
\mathrm{pH} \\
9.6\end{array}$ & SSA & $\begin{array}{c}\text { SSA + } \\
0.05 \% \\
\text { suramin }\end{array}$ & $\begin{array}{l}\text { SSA + } \\
\text { ML-Ca }\end{array}$ & \\
\hline \multirow[t]{6}{*}{ E. faecalis } & ATCC 27959 & $3+$ & $3+$ & $3+$ & $2+$ & - & $3+$ & $2+$ & $4+$ & $2+$ & - & $2+$ & E-I \\
\hline & ATCC 19433 & $3+$ & $3+$ & $3+$ & $2+$ & - & $3+$ & $2+$ & $4+$ & $2+$ & - & $2+$ & E-I \\
\hline & ATCC 11700 & $3+$ & $3+$ & $3+$ & $2+$ & - & $2+$ & $2+$ & $4+$ & $2+$ & - & $2+$ & E-I \\
\hline & ATCC 33186 & $3+$ & $3+$ & $3+$ & $2+$ & - & $3+$ & $2+$ & $4+$ & $2+$ & - & $2+$ & E-I \\
\hline & CCM 2541 & $3+$ & $3+$ & $3+$ & $2+$ & - & $3+$ & $3+$ & $3+$ & $2+$ & - & $2+$ & E-I \\
\hline & ATCC 6055 & $3+$ & $3+$ & $3+$ & $2+$ & - & $3+$ & $2+$ & $4+$ & $2+$ & - & $2+$ & E-I \\
\hline E. malodoratus & SS 1266 & $3+$ & $3+$ & $3+$ & $1+$ & - & $3+$ & $1+$ & $4+$ & $2+$ & - & $2+$ & E-I \\
\hline \multirow{2}{*}{ E. faecium } & ATCC 19434 & $3+$ & $1+$ & $3+$ & $1+$ & $2+$ & $2+$ & $1+$ & - & $3+$ & $2+$ & $3+$ & E-II \\
\hline & ATCC 12819 & $3+$ & $1+$ & $3+$ & $1+$ & $2+$ & $2+$ & $1+$ & - & $3+$ & $2+$ & $3+$ & E-II \\
\hline \multirow[t]{2}{*}{ E. durans } & ATCC 6056 & $3+$ & $2+$ & $3+$ & $2+$ & $2+$ & $2+$ & $1+$ & - & $3+$ & $2+$ & $3+$ & E-II \\
\hline & ATCC 19432 & $3+$ & $2+$ & $3+$ & $2+$ & $2+$ & $2+$ & $1+$ & - & $3+$ & $2+$ & $3+$ & E-II \\
\hline Enterococcus & ATCC 12755 & $3+$ & - & $3+$ & $1+$ & $2+$ & - & - & - & $1+$ & $1+$ & $2+$ & E-III \\
\hline \multirow{3}{*}{ casseliflavus } & ATCC 14436 & $3+$ & - & $3+$ & $1+$ & $2+$ & - & - & - & $1+$ & $1+$ & $2+$ & E-III \\
\hline & ATCC 25788 & $3+$ & - & $3+$ & $1+$ & $2+$ & - & - & - & $1+$ & $1+$ & $2+$ & E-III \\
\hline & ATCC 25789 & $2+$ & - & $3+$ & $1+$ & $2+$ & - & - & - & $1+$ & $1+$ & $2+$ & E-III \\
\hline E. avium & ATCC 14025 & $1+$ & - & - & - & - & - & - & - & - & - & $1+$ & E-IV \\
\hline E. pseudoavium & SS 1277 & $1+$ & - & - & - & - & - & - & - & - & - & $1+$ & E-IV \\
\hline E. raffinosus & SS 1278 & $1+$ & - & - & - & - & - & - & - & - & - & $1+$ & E-IV \\
\hline E. solitarius & SS 1279 & $1+$ & - & - & - & - & - & - & - & - & - & $1+$ & E-IV \\
\hline E. hirae & ATCC 8043 & $4+$ & $3+$ & $4+$ & $3+$ & $3+$ & $3+$ & $3+$ & $2+$ & $2+$ & $1+$ & $4+$ & $\mathrm{E}-\mathrm{V}$ \\
\hline E. gallinarum & CCM 2518 & $2+$ & $2+$ & $2+$ & - & $1+$ & $1+$ & - & $1+$ & - & - & $2+$ & E-VI \\
\hline E. mundtii & CCM 2801 & $2+$ & $1+$ & $2+$ & $1+$ & - & $1+$ & $1+$ & $2+$ & - & - & - & E-VII \\
\hline S. bovis & ATCC 9809 & - & $\mathrm{NG}^{c}$ & - & 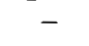 & NG & NG & $\mathrm{NG}$ & - & NG & NG & NG & \\
\hline
\end{tabular}

${ }^{a}$ Unless indicated otherwise, the preparations contained $M$. lysodeikticus obtained from Sigma as the substrate for lysis.

This preparation contained $M$. luteus ML-Ca as the substrate for lysis.

${ }^{c}$ NG, no growth. 
TABLE 3-Continued

\begin{tabular}{|c|c|c|c|c|c|c|c|c|c|c|}
\hline \multirow{2}{*}{$\begin{array}{c}\text { Arginine } \\
\text { dehydrolase }\end{array}$} & \multirow{2}{*}{$\begin{array}{c}\text { Litmus } \\
\text { milk }\end{array}$} & \multicolumn{3}{|c|}{ Growth at: } & \multirow{2}{*}{ Amylase } & \multirow{2}{*}{ Hemolysis } & \multirow{2}{*}{ Pigment } & \multirow{2}{*}{ Motility } & \multirow[t]{2}{*}{ Species } & \multirow[t]{2}{*}{ Lyogroup } \\
\hline & & pH 9.6 & $10^{\circ} \mathrm{C}$ & $45^{\circ} \mathrm{C}$ & & & & & & \\
\hline+ & + & + & + & + & - & $\mathrm{v}^{a}$ & - & - & E. faecalis & E-I \\
\hline+ & - & + & + & + & - & $\mathrm{v}$ & - & - & E. faecalis & E-I \\
\hline+ & + & + & + & + & - & $\mathrm{v}$ & - & - & E. faecalis & E-I \\
\hline+ & + & + & + & + & - & $\mathrm{v}$ & - & - & E. faecalis & E-I \\
\hline+ & $\mathrm{v}$ & + & + & + & - & $\mathrm{v}$ & - & - & E. faecium & E-II \\
\hline+ & $\mathrm{v}$ & + & + & + & - & $\mathrm{v}$ & - & - & E. faecium & E-II \\
\hline+ & $\mathrm{v}$ & + & + & + & - & v & - & - & E. faecium & E-II \\
\hline+ & - & + & + & + & - & - & - & - & $E$. durans & E-II \\
\hline+ & $\mathrm{v}$ & + & + & + & - & - & + & + & E. casseliflavus & E-III \\
\hline- & - & + & - & + & - & - & - & - & E. avium & E-IV \\
\hline- & - & + & + & + & - & - & - & - & E. pseudoavium & E-IV \\
\hline- & - & + & - & + & - & - & - & - & E. raffinosus & E-IV \\
\hline+ & $\mathrm{v}$ & + & + & + & - & - & - & - & E. hirae & E-V \\
\hline+ & - & + & + & + & - & - & - & + & E. gallinarum & E-VI \\
\hline+ & - & + & + & + & - & - & + & - & E. mundtii & E-VII \\
\hline- & $\mathrm{v}$ & + & - & + & + & - & - & - & S. bovis & $\mathbf{0}$ \\
\hline
\end{tabular}

bacteriolytic activities of other streptococci belonging to antigenic groups A, B, C, F, and G and of some Streptococcus pneumoniae and viridans strains. Group A streptococci exhibited bacteriolytic activity on $M$. lysodeikticus plates, while the other groups of streptococci which we tested did not. However, the group A streptococci lacked bacteriolytic activity on media supplemented with either sodium azide (SSA) or suramin and at $\mathrm{pH} 9.6$.

\section{DISCUSSION}

In this work we found that all of the strains belonging to the genus Enterococcus that were isolated in a clinical microbiology laboratory, which represented the most common enterococcal species defined to date, exhibit bacteriolytic activity on plates containing heat-killed cells of $M$. luteus. We found that this activity has uniform properties in all strains of the same species, but is clearly different for strains of different species. In contrast, none of the four nonenterococcal group D streptococci ( $S$. bovis) which we tested exhibited bacteriolytic activity that was detectable in the system which we used. Such findings closely resemble the findings described previously for staphylococci, in which almost all of the strains of the genus (except a very few) exhibited bacteriolytic activity $(32,33,37,39,41,42)$. Likewise, in the system described above, lytic activity was not exhibited by group D streptococci which did not belong to the genus Enterococcus, as well as other medically important streptococci, with the exception of Streptococcus pyogenes. However, $S$. pyogenes exhibited a lytic activity pattern which was clearly different from the patterns of the enterococci.

On the basis of the results of our analysis of lytic activity properties, we succeeded in developing a scheme for the identification of enterococcal species. This scheme appears to be reliable and easy to reproduce, since a trained technician was able to report the same bacteriolysis scores as we did. In addition, most enterococcal groups are clearly divided by qualitative differences into bacteriolytic patterns,

TABLE 5. Simplified scheme for the identification of group D streptococci on the basis of bacteriolytic activity

\begin{tabular}{|c|c|c|c|c|c|c|c|c|c|c|c|}
\hline \multirow[b]{2}{*}{ Species } & \multirow[b]{2}{*}{$\begin{array}{l}\text { No. of } \\
\text { strains }\end{array}$} & \multirow[b]{2}{*}{ Lyogroup } & \multicolumn{6}{|c|}{ Bacteriolytic activity on the following medium: } & \multicolumn{3}{|c|}{ Additional tests } \\
\hline & & & THD & $\begin{array}{c}\text { THO + } \\
0.02 \% \\
\text { sodium } \\
\text { azide }\end{array}$ & $\begin{array}{c}\text { TA + } \\
0.04 \% \\
\text { bile } \\
\text { salts }\end{array}$ & $\begin{array}{r}\mathrm{TA}+ \\
0.05 \% \\
\text { suramin }\end{array}$ & $\begin{array}{c}\text { TA at } \\
\text { pH } \\
9.6\end{array}$ & $\begin{array}{l}\text { SSA + } \\
\text { ML-Ca }\end{array}$ & $\begin{array}{l}\text { Arabinose } \\
\text { fermen- } \\
\text { tation }\end{array}$ & $\begin{array}{l}\text { Raffinose } \\
\text { fermen- } \\
\text { tation }\end{array}$ & $\begin{array}{c}\text { Arginine } \\
\text { dehydro- } \\
\text { lase } \\
\text { production }\end{array}$ \\
\hline E. faecalis & 193 & E-I & $3+$ & $3+$ & $2+$ & - & $4+$ & $2+$ & - & $\mathrm{v}^{a}$ & + \\
\hline E. malodoratus & 2 & E-I & $3+$ & $3+$ & $1+$ & - & $4+$ & $2+$ & - & + & - \\
\hline E. faecium & 43 & E-II & $3+$ & $1+$ & $1+$ & $2+$ & - & $3+$ & + & $\mathrm{v}$ & + \\
\hline E. durans & 3 & E-II & $3+$ & $1+$ & $2+$ & $2+$ & - & $3+$ & - & - & + \\
\hline E. casseliflavus & 8 & E-III & $3+$ & - & $1+$ & $2+$ & - & $2+$ & + & + & + \\
\hline E. avium & 8 & E-IV & $1+$ & - & - & - & - & $1+$ & + & - & - \\
\hline E. pseudoavium & 2 & E-IV & $1+$ & - & - & - & - & $1+$ & - & - & - \\
\hline E. raffinosus & 3 & E-IV & $1+$ & - & - & - & - & $1+$ & + & + & - \\
\hline E. solitarius & 1 & E-IV & $1+$ & - & - & - & - & $1+$ & - & - & + \\
\hline E. hirae & 9 & E-V & $4+$ & $3+$ & $3+$ & $3+$ & $2+$ & $4+$ & + & + & + \\
\hline E. gallinarum & 4 & E-VI & $2+$ & $2+$ & - & $1+$ & $1+$ & $2+$ & + & + & + \\
\hline E. mundtii & 5 & E-VII & $2+$ & $1+$ & $1+$ & - & $2+$ & - & + & $\mathbf{v}$ & + \\
\hline S. bovis & 4 & 0 & - & $\mathrm{NG}^{b}$ & - & NG & - & NG & - & + & - \\
\hline
\end{tabular}

${ }^{a} \mathrm{v}$, variable reaction.

${ }^{b} \mathrm{NG}$, no growth. 
TABLE 6. Bacteriolytic activities of streptococci belonging to antigenic groups other than group D

\begin{tabular}{|c|c|c|c|c|c|c|}
\hline \multirow{2}{*}{ Antigenic group } & \multirow{2}{*}{$\begin{array}{l}\text { No. of } \\
\text { strains }\end{array}$} & \multicolumn{5}{|c|}{$\begin{array}{l}\text { Bacteriolytic activity on } \\
\text { the following medium: }\end{array}$} \\
\hline & & THD & THO & SSA & $\begin{array}{c}\text { TA + } \\
0.05 \% \\
\text { suramin }\end{array}$ & $\begin{array}{c}\text { TA at } \\
\text { pH } 9.6\end{array}$ \\
\hline$\overline{\mathrm{A}}$ & 21 & $2+a$ & $2+$ & - & - & - \\
\hline B & 8 & - & - & $\mathrm{ND}^{b}$ & ND & ND \\
\hline $\mathrm{C}$ & 4 & - & - & ND & ND & ND \\
\hline $\mathrm{F}$ & 5 & - & - & ND & ND & ND \\
\hline $\mathrm{G}$ & 5 & - & - & ND & ND & ND \\
\hline Pneumococci & 6 & - & - & ND & ND & ND \\
\hline Viridans streptococci & 40 & - & - & ND & ND & ND \\
\hline
\end{tabular}

a The lysis halos around these colonies were rather turbid and had illdefined edges.

${ }^{b} \mathrm{ND}$, not determined.

which are easy to detect; quantitative subtle separations usually had less importance for the differentiation of single groups or species.

The fact that another important microbial group produces exocellular bacteriolytic enzymes whose properties allow both separation of the group from the other groups and subdivision into species indicates, as previously suggested $(30,32,36)$, that the study of bacteriolytic activity may be of practical use in bacterial taxonomy and may constitute one of the standard characteristics that should be determined for species recognition and identification. Actually, elsewhere we intend to describe the bacteriolytic activity of a number of enterobacterial species.

The purified bacteriolytic enzyme of Staphylococcus aureus has been shown to play some role in staphylococcal pathogenicity $(28,31,36,38)$. Worthy of note in this context is the fact that some of the best enterococcal bacteriolytic species are among the most important species in human pathogenicity. It would be interesting to evaluate whether enterococcal lytic enzymes also play such a role in bacterial pathogenicity.

\section{ACKNOWLEDGMENTS}

This work was supported by grant 91.00221.PF41 from the FATMA target projects to R.P. and by Biotechnology and Bioinstrumentation grant 90.0098 .70 from the Consiglio Nazionale delle Ricerche to M.C.T.

We thank G. Foddis for invaluable technical assistance.

\section{REFERENCES}

1. Atkinson, B. A., and V. Lorian. 1984. Antimicrobial agent susceptibility patterns of bacteria in hospitals from 1971 to 1982 . J. Clin. Microbiol. 20:791-796.

2. Birch, B. R., M. G. L. Keaney, and L. A. Ganguli. 1984. Antibiotic susceptibility and biochemical properties of Streptococcus faecalis strains reacting with both $\mathrm{D}$ and $\mathrm{G}$ antigens. J. Clin. Pathol. 37:1289-1292.

3. Bosley, G. S., R. R. Facklam, and D. Grossman. 1983. Rapid identification of enterococci. J. Clin. Microbiol. 18:1275-1277.

4. Collins, M. D., R. R. Facklam, J. A. E. Farrow, and R. Williamson. 1989. Enterococcus raffinosus sp. nov., Enterococcus solitarius sp. nov. and Enterococcus pseudoavium sp. nov. FEMS Microbiol. Lett. 57:283-288.

5. Collins, M. D., J. A. Farrow, and D. Jones. 1986. Enterococcus mundtii sp. nov. Int. J. Syst. Bacteriol. 36:8-12.

6. Collins, M. D., and D. Jones. 1979. The distribution of isoprenoid quinones in streptococci of serological group D and N. J. Gen. Microbiol. 114:27-33.
7. Collins, M. D., D. Jones, J. A. E. Farrow, R. Kilpper-Balz, and K. H. Schleifer. 1984. Enterococcus avium nom. rev., comb. nov; E. casseliflavus nom. rev., comb. nov.; E. durans nom. rev., comb. nov.; E. gallinarum comb. nov.; and E. malodoratus sp. nov. Int. J. Syst. Bacteriol. 34:220-223.

8. Colman, G., and L. C. Ball. 1984. Identification of streptococc in a medical laboratory. J. Appl. Bacteriol. 57:1-14.

9. Devriese, L. A., A. Van de Kerckhove, R. Kilpper-Balz, and K. H. Schleifer. 1987. Characterization and identification of Enterococcus species isolated from the intestine of animals. Int. J. Syst. Bacteriol. 37:257-259.

10. Ellner, P. D., D. A. Williams, M. E. Hosmer, and M. A. Coherford. 1985. Preliminary evaluation of a rapid colorimetric method for the presumptive identification of group A streptococci and enterococci. J. Clin. Microbiol. 22:880-881.

11. Facklam, R. R. 1972. Recognition of group D streptococcal species of human origin by biochemical and physiological tests. Appl. Microbiol. 23:1131-1139.

12. Facklam, R. R., and R. B. Carey. 1985. Streptococci and aerococci, p. 154-175. In E. H. Lennette, A. Balows, W. J. Hausler, and H. J. Shadomy (ed.), Manual of clinical microbiology, 4th ed. American Society for Microbiology, Washington, D.C

13. Facklam, R. R., and M. D. Collins. 1989. Identification of Enterococcus species isolated from humans by a conventional test scheme. J. Clin. Microbiol. 27:731-734.

14. Facklam, R. R., L. G. Thacker, B. Fox, and B. Enriquez. 1982. Presumptive identification of streptococci with a new test system. J. Clin. Microbiol. 15:987-990.

15. Farrow, J. A., and M. D. Collins. 1985. Enterococcus hirae, a new species that includes amino acid assay strain NCDO 1258 and strains causing growth depression in young chickens. Int. J. Syst. Bacteriol. 35:73-75.

16. Farrow, J. A. E., D. Jones, B. A. Phillips, and M. D. Collins. 1983. Taxonomic studies on some group D streptococci. J. Gen. Microbiol. 129:1423-1432.

17. Fertally, S. S., and R. R. Facklam. 1987. Comparison of physiological tests used to identify non-beta-hemolytic aerococci, enterococci, and streptococci. J. Clin. Microbiol. 25:1855-1850

18. Hardie, J. M. 1986. Genus Streptococcus, p. 1043-1047. In P. H. A. Sneath, N. S. Mair, M. E. Sharpe, and J. G. Holt (ed.), Bergey's manual of systematic bacteriology, vol. 2. The Williams \& Wilkins Co., Baltimore.

19. Ike, Y., H. Hashimoto, and D. B. Clewell. 1987. High incidence of hemolysin production by Enterococcus (Streptococcus) faecalis strains associated with human parenteral infections. J. Clin. Microbiol. 25:1524-1528.

20. Kilpper-Balz, R., G. Fisher, and K. H. Schleifer. 1982. Nucleic acid hybridization of group $\mathrm{N}$ and group D streptococci. Curr. Microbiol. 7:245-250.

21. Kim, M. J., M. Weiser, S. Gottschall, and E. Randall. 1987. Identification of Streptococcus faecalis and Streptococcus faecium and susceptibility studies with newly developed antimicrobial agents. J. Clin. Microbiol. 25:787-790.

22. Mayer, K. H., and S. H. Zimmer. 1985. Bacterial pathogens of increasing significance in hospital acquired infections. Rev. Infect. Dis. 7:371-379.

23. Moellering, R. C., and D. J. Krogstad. 1979. Antibiotic resistance in enterococci. Microbiol. Ser. 197:295-298.

24. Parker, M. T., and L. Y. Ball. 1976. Streptococci and aerococci associated with systemic infections in man. J. Med. Microbiol. 9:275-302.

25. Pepper, K., T. Horaud, C. Le Bouguènec, and G. De Cespedes. 1987. Location of antibiotic resistance markers in clinical isolates of Enterococcus faecalis with similar antibiotypes. Antimicrob. Agents Chemother. 31:1394-1402.

26. Pompei, R., E. Caredda, V. Piras, C. Serra, and L. Pintus. 1990 Production of bacteriolytic activity in the oral cavity by nutritionally variant streptococci. J. Clin. Microbiol. 28:1623-1627.

27. Ruoff, K. L. 1988. Streptococcus anginosus ("Streptococcus milleri"'): the unrecognized pathogen. Clin. Microbiol. Rev 1:102-108.

28. Satta, G., B. Azzarone, P. E. Varaldo, R. Fontana, and S. 
Valisena. 1980. Stimulation of spreading of trypsinized human fibroblasts by lysozymes from Staphylococcus aureus, hen egg white and human urine. In Vitro 16:738-750.

29. Satta, G., G. Grazi, P. E. Varaldo, and R. Fontana. 1979. Detection of bacterial phosphatase by means of an original and simple test. J. Clin. Pathol. 32:391-395.

30. Satta, G., F. Palmas, P. E. Varaldo, G. Grazi, O. Soro, and R. Pompei. 1983. Analysis of the bacteriolytic pattern as a tool for species separation and identification in Micrococcaceae, streptococci and Pseudomonadaceae, p. 309-316. In K. H. Spitzy and K. Karrer (ed.), Proceedings of the 13th International Congress on Chemotherapy. Verlag H. Egermann, Vienna.

31. Satta, G., P. E. Varaldo, B. Azzarone, and C. A. Romanzi. 1979. Effects of Staphylococcus aureus lysozyme on human fibroblasts. Cell Biol. Int. Rep. 3:525-530.

32. Satta, G., P. E. Varaldo, G. Grazi, and R. Fontana. 1977 Bacteriolytic activity of staphylococci. Infect. Immun. 16:3742.

33. Satta, G., P. E. Varaldo, M. Tenca, and L. Rodin. 1978. The relevance of bacteriolytic activity in the taxonomy of Micrococcaceae: failure of its production by Micrococcus and Planococcus as opposed to Staphylococcus. J. Gen. Microbiol. 109:385388.

34. Schleifer, K. H., and R. Kilpper-Bälz. 1984. Transfer of Streptococcus faecalis and Streptococcus faecium to the genus Enterococcus nom. rev., as Enterococcus faecalis and Enterococcus faecium comb. nov. Int. J. Syst. Bacteriol. 34:31-34.

35. Traub, W. H., M. Spohr, and D. Bauer. 1986. Streptococcus faecalis in vitro susceptibility to antimicrobial drugs, single and combined with and without defibrinated human blood. Chemotherapy 32:270-285.

36. Valisena, S., C. Pruzzo, P. E. Varaldo, and G. Satta. 1987.
Interference of a Staphylococcus aureus bacteriolytic enzyme with polymorphonuclear leucocyte function, p. 411-420. In F. Cabello and C. Pruzzo (ed.), Bacteria, complement and the phagocytic cell. Springer-Verlag, Berlin.

37. Valisena, S., P. E. Varaldo, and G. Satta. 1982. Purification and characterization of three separate bacteriolytic enzymes excreted by Staphylococcus aureus, Staphylococcus simulans, and Staphylococcus saprophyticus. J. Bacteriol. 151:636-647.

38. Varaldo, P. E., F. Biavasco, C. Pruzzo, and G. Satta. 1981 Interference of Staphylococcus glucosaminidase with mitogen responsiveness by human lymphocytes. Zentralbl. Bakteriol. Mikrobiol. Hyg. Suppl. 10:895-899.

39. Varaldo, P. E., G. Grazi, G. Cisani, and G. Satta. 1979. Routine separation of staphylococci from micrococci based on bacteriolytic activity production. J. Clin. Microbiol. 9:147-148.

40. Varaldo, P. E., G. Grazi, O. Soro, G. Cisani, and G. Satta. 1980 Simplified lyogroup system, a new method for routine identification of staphylococci: its description, and comparison with three other methods. J. Clin. Microbiol. 12:63-68.

41. Varaldo, P. E., and G. Satta. 1978. Grouping of staphylococci on the basis of their bacteriolytic activity patterns: a new approach to the taxonomy of the Micrococcaceae. II. Strain characteristics of 1,053 strains subdivided into "lyogroups." Int. J. Syst. Bacteriol. 28:148-153.

42. Varaldo, P. E. G. Satta, G. Grazi, and C. A. Romanzi. 1978 Grouping of staphylococci on the basis of their bacteriolytic patterns: a new approach to the taxonomy of Micrococcaceae. I. Identification of six different lyogroups. Int. J. Syst. Bacteriol. 28:141-147.

43. Williamson, R., L. Gutmann, T. Horand, F. Delbos, and J. F. Acar. 1986. Use of penicillin-binding proteins for the identification of enterococci. J. Gen. Microbiol. 132:1929-1937. 